\title{
The Changing Nature of the Peri-Urban Zone in Africa: Evidence from Dar-es-Salaam, Tanzania
} JOHN BRIGGS* \& DAVIS MWAMFUPE $\dagger$

*Department of Geography and Topographic Science, University of Glasgow, Glasgow G12 8QQ; $\dagger$ Department of Geography, University of Dar-esSalaam, PO Box 35049, Dar-es-Salaam, Tanzania

\begin{abstract}
Research on the peri-urban zones of African cities since the mid-1980s has focused around three main themes, these being peri-urban agriculture as a survival strategy, debates about the relative efficiencies of peri-urban agriculture, and the question of production priorities. Drawing on recent evidence from Dar-es-Salaam in Tanzania, this paper suggests that a combination of structural adjustment measures and the eased economic crisis in Tanzania has changed conditions, the result of which has been the increasing commodification of land in the peri-urban zone during the 1990s. This has turned the peri-urban zone more into a zone of investment and economic opportunity, rather than a zone of survival, with the result that the poorer urban groups are being increasingly excluded. A further complication concerns confusion arising out of current Tanzanian land law, and particularly the tensions between customary and statutory law.
\end{abstract}

Key words: peri-urban zone, peri-urban agriculture, Dar-es-Salaam.

\section{The peri-urban zone in Africa: three research themes}

By the early 1990s the peri-urban areas of African cities had become commonly represented as zones of economic survival for the growing and increasingly hardpressed urban populations of the continent. Until then, with notable exceptions (for example, Mortimore, 1975; Swindell, 1988), interest in the peri-urban zones of African cities was minimal. This is not surprising as the most urgent problems associated with Africa's rapidly urbanising cities were seen to be those of housing shortages, spontaneous settlements, unemployment, underemployment, food supply issues and so on. Moreover, as many migrants to the cities came from distant areas, there was frequently little or no tradition of cultural or economic contact with the city's peri-urban zone. The symbiosis of the economic and social structures of the city with its immediate peri-urban zone and hinterland, as argued by Bryant \& Johnson (1992) in a broader context, was largely absent from the African city, apart from some cities in the West African savanna. Arguably this was aggravated by the fact that many African cities were colonial creations and were established to serve external linkages to the metropole, resulting in at best only weak linkages with their own domestic hinterlands (Simon, 1992).

Recent interest in the peri-urban zone of African cities has coincided with a broader interest in the expansion of urban agriculture, an agriculture carried out either on small plots within the existing built-up area or on land in the peri-urban zone of the city. Much of the debate has focused around three main themes. The first has been concerned with the underlying motivations for the expansion of 
urban agriculture. With the squeeze on urban household incomes, particularly during the 1980s, urban residents increasingly employed a range of coping strategies involving various informal economic activities, what Rakodi (1995) has termed a portfolio of tangible and intangible assets, where previously nonearning household members enter the petty commodity sector, existing wageearners take on supplementary cash-earning activities, and urban and peri-urban land is cultivated with food crops. This strategy, it is argued, is pursued when wage levels are no longer capable of purchasing enough food for household needs. In a Nairobi survey, for example, more than $75 \%$ of farmers cited the need for household food, or even outright hunger in some cases, as a motivation for engaging in urban agriculture (Freeman, 1991). Similarly, in Lusaka $78 \%$ of garden (urban) plots and $82 \%$ of peri-urban plots were being farmed because of a lack of purchasing power for food within urban households, producing an urban landscape in which Lusaka has been described as the world capital of urban cultivation (Sanyal, 1986, 1987). A common view of the cause of these pressures rests with the implementation of structural adjustment strategies throughout many African countries (Sanyal, 1987; Gefu, 1992). Indeed, Smith $(1998,214)$ is of the view that 'there has been an expansion of urban cultivation in recent years as structural adjustment reduces incomes and, together with increased capitalisation of food retailing, raises costs of purchased commodities'. Whether this is the case or not, there is some degree of consensus that urban agriculture has the advantage of reducing household vulnerability to economic fluctuations in the urban economy, as well as of creating valuable productive areas from waste land and improving the general environment with activities such as tree planting (Drakakis-Smith, 1991, 1994).

The second theme has focused on critiques of urban agriculture. Some observers have developed the argument that urban farming reduces the social costs of labour reproduction by transferring the burden of maintaining the labour force from the state to labour itself, hence driving down labour costs (Rakodi, 1985; Freeman, 1991). This view has been criticised by Sanyal (1987), however, arguing that the state has consistently opposed urban agriculture through legislation and, if necessary, force. Indeed, it can be further argued that such postcolonial legislation is itself a hangover from colonial planning principles. Typically, the state continues to see urban agriculture as a visible sign of the lack of modernity in an urban setting (Egziabher et al., 1994), or what Sanyal (1987, 197) has called 'manifestations of rural habits' in an urban environment. It has been suggested that there exists among politicians and development planners a rather simplistic view that the rural areas should produce food, and the urban should concentrate on non-agricultural activities (Rogerson, 1993; Mbiba, 1994). In some cases, colonial environmental laws have been invoked on the grounds that such areas of urban agriculture constitute a public health nuisance and may encourage the spread of disease, especially malaria. Some see urban agriculture as only a marginal activity in terms of the overall urban economy (Freeman, 1991), and therefore it is not seen as worthy of support by local or national authorities. Indeed, Gefu $(1992,301)$ has observed that urban agriculture has increased in Nigeria to supplement declining real urban wages 'despite the evident diseconomies of scale and low profit margins'. 
These views, however, have been refuted by others who have noted both the prevalence and resilience of urban agriculture in African cities, as well as the importance of subsistence food production in circumstances where up to three-quarters of the urban poor's income may be spent on food purchases (Sanyal, 1987; Mosha, 1991; Drakakis-Smith 1991; Memon \& Lee-Smith, 1993; Egziabher et al., 1994; Maxwell, 1996). In a survey of six towns in Tanzania, Mlozi et al. (1992) observe that urban agriculture is seen by people as a sound cash-saving strategy for households, releasing money that can then be spent elsewhere within the household's consumption patterns. Significantly, Maxwell $(1995,1679)$ concludes that in Kampala 'semisubsistence production in the city is not marginal, but in fact critical to urban household food security'. He goes on to show that about $35 \%$ of the city's households engage in urban agriculture and some $56 \%$ of the land surface of Kampala city is used for agriculture. Interestingly, although urban agriculture has been characterised as a rural residual, there is strong evidence from a number of cities to suggest that the decision to cultivate is taken by people who have been resident longest in the city, and not by recent arrivals from the countryside. The reason is that cultivation has significant resource implications, with the result that people only commit such resources once they are established in the city (Rakodi, 1985; Sanyal, 1987; Lado, 1990; Freeman, 1991; Maxwell, 1995).

The third theme has been concerned with production priorities, and suggests that urban agricultural production is orientated predominantly towards household consumption (Sanyal, 1987; Rakodi, 1988; Briggs, 1991; Freeman, 1991; Drakakis-Smith, 1991; Mlozi et al., 1992; Maxwell, 1995). In Dar-es-Salaam, 'agricultural production in the peri-urban zone is characterised by the need to satisfy household consumption needs ... surpluses are sold, but not on the commercial scale expected, given the relative proximity of the vast urban food market of Dar-es-Salaam' (Briggs, 1990, 188), with as many as $92 \%$ of farmers selling none of their maize production, for example. It is a similar story elsewhere. In Lusaka only $10 \%$ of production is sold (Sanyal, 1987), whilst in Nairobi, $85 \%$ of crops are consumed within the household (Freeman, 1991). The problem with this kind of representation is that whilst it emphasises household food production, it underplays the growing importance of commercial production in urban environments, what Drakakis-Smith $(1991,56)$ calls 'the rise of the producerentrepreneur'. By the mid-1990s, an increasing element of small-scale commercial production in urban and peri-urban agriculture was being acknowledged (Smith, 1998). In both Nairobi and Harare, farmers have been selling crops as sources of cash income, not just growing them as sources of household food supply, for some years, with about $30 \%$ of farmers in the Nairobi sample intending to sell at least part of their crop (Freeman, 1991). Further, a common representation is that it is only the urban poor who are engaged in urban agriculture, that urban agriculture is the sole preserve of low-income households (Sanyal, 1987). However, there is increasing evidence that middle-income groups, and even capital investors, may be involved, because they have mobility, capital and 'contacts' giving them greater likelihood of success (Drakakis-Smith, 1991, 1994; Smith, 1998). Significantly, over one-half of the cultivators in a survey in Nairobi also had full- or part-time jobs in the city (Freeman, 1991). 
What is missing from these debates, however, is a more recently developed fourth theme, the extent to which a land market, especially in the peri-urban areas, has developed. Certainly, by the end of the 1980s in Dar-es-Salaam there had developed an informal land market leading to the commoditisation of land, even though it was strictly illegal and contrary to government policy (Briggs, 1991; Kombe, 1994). Similarly, with regard to Kampala (Maxwell, 1995, 1675) has observed that '.. in areas where people have been cultivating for years without being harassed by either municipal authorities or private landowners, a secondary land market has emerged for the buying and selling of use-rights in informally occupied land'. It is the aim of this paper, therefore, to explore some of these more recent processes, in the context of Dar-es-Salaam, Tanzania, and to offer some insights as to how these recent experiences may inform more general debates and issues with regard to urban agriculture in contemporary African cities.

\section{Farmers' attitudes to peri-urban land use and ownership in Dar-es-Salaam}

The results presented in Tables 1 and 2 were collected as part of a broader survey in 1996 of 550 farmers and landowners from 11 peri-urban villages around the city of Dar-es-Salaam in Tanzania. Table 1 clearly suggests that a land market has developed in the peri-urban zone of Dar-es-Salaam and is having an impact on farmers' intentions and plans. Over one-half of the surveyed farmers take the view that further land expansion is being restricted by high land prices, whilst another $30 \%$ are not sure; only $17.5 \%$ disagree that farm expansion is being limited by high land prices. This reflects increases in land pressures during the 1990s, and especially so since the middle of the decade. Land prices have been rapidly increasing to reflect this. At the start of the 1990s, ownership of even the most expensive and desirable land in the peri-urban zone was selling for about TShs 100,000 per acre (or approximately TShs 350,000 at 1998 equivalent prices), whereas by 1998 similar land was fetching upwards of TShs 5 million per acre.' This clearly represents an appreciable increase in real prices. Land prices continue to rise, and in December 1998, it was reported that a 7-hectare plot with one completed house on it sold for TShs 60 million in the Mbezi area of the western peri-urban zone. Nonetheless, despite the development of an appreciable land market, farmers' intentions towards selling land and/or leaving farming are rather less well-defined. Whilst over $35 \%$ of farmers would agree that they are likely to sell land, almost $40 \%$ are unlikely to. It is even stronger with regard to leaving farming, where nearly $45 \%$ appear unlikely to leave farming. So although land prices are high and seemingly attractive, many farmers are still prepared to hold on to land and to keep farming. There is, nonetheless, a sizeable minority who are prepared to sell land and to leave farming altogether, and who are looking to participate actively in the land market.

When the data are broken down into rather more detail, three interesting trends emerge (Table 2). Farm size clearly has an impact on the likelihood of selling land. Only $11 \%$ of farmers with farms less than 1 hectare in area, and fewer than $7 \%$ of farmers with farms between 1 and 4 hectares, are likely to sell farmland. Conversely, almost $70 \%$ of those with farms in excess of 10 hectares 
Table 1. Farmers' intentions with regard to peri-urban agriculture.

\begin{tabular}{lccc}
\hline & Disagree & Not sure & Agree \\
\hline Farm expansion limited by high land prices & 17.5 & 30.0 & 52.5 \\
Likely to sell farmland & 39.5 & 24.9 & 35.6 \\
Likely to leave farming & 44.7 & 22.5 & 32.8 \\
\hline
\end{tabular}

Table 2. Farmers' intentions.

\begin{tabular}{lcccc}
\hline (1) by farm size (hectares) & $<\mathbf{1}$ & $\mathbf{1 - 4}$ & $\mathbf{5 - 1 0}$ & $>\mathbf{1 0}$ \\
Likely to sell farmland & 11.0 & 6.8 & 31.3 & 69.4 \\
Likely to leave farming & 28.0 & 26.0 & 32.0 & 12.0 \\
(2) by land tenure & & & Right of \\
& Rented & Customary & Bought & occupancy \\
Likely to sell farmland & 1.5 & 62.5 & 16.0 & 3.0 \\
Likely to leave farming & 1.2 & 24.0 & 11.2 & 23.0 \\
(3) by crop category & & Food crop & Cash crop & \\
Likely to sell farmland & & 44.0 & 20.8 & \\
Likely to leave farming & & 31.0 & 13.0 & \\
\hline
\end{tabular}

Note: data given are expressed as percentages of farmers in each category who answered affirmatively to the questions about selling farmland and leaving farming.

are likely to sell farmland. At first sight this may seem strange in that larger farms are likely to be more economically viable. Hence, it might be anticipated that pressure to sell would be less, whereas smaller farms, perhaps being generally more marginal, would be expected to be more vulnerable to external purchasing pressures. However, in the peri-urban zone of Dar-es-Salaam, the typical pattern of land selling is such that few farmers sell all their farmland in one single transaction. More typically, land is sold off in stages, as small plots, to individuals who may then build a house or establish a small farm themselves. Consequently, it is the owners with larger landholdings who have the land available to sell in such an attritional manner.

Secondly, land tenure seems to have an impact on farmers' intentions. Over $62 \%$ of those farmers owning land through customary rights are more likely to sell land than those who have acquired land through other means. This group of farmers, mainly Zaramo people, the indigenous ethnic group of the Dar-esSalaam region, has acquired land rights through tribal occupancy, and therefore lay claim to land through customary rights enshrined in the Land Ordinance of 1923, later amended by the Regulation of Land Tenure Act in 1992. Land 'ownership' has been established through agreements within Zaramo clans, and although all land in Tanzania is legally held by the state on behalf of the people, very few disputes take place over customary ownership, and if they do, such disputes are usually resolved within the tribal unit. It would appear that one of the biggest beneficiaries of the expansion of the city of Dar-es-Salaam, and its burgeoning land market, have been Zaramo landowners. The other three tenure groups have 
far less interest in selling land, albeit for rather differing reasons. Those who have acquired land through Right of Occupancy have done so by becoming members of village communities in the peri-urban zone. This was particularly common in the mid-1970s during Tanzania's villagisation campaign when many recent urban arrivals took the opportunity to gain access to land close to the city. This had the advantage of securing a food supply, as well as allowing easy access to the city for employment. Those who acquired such land did so as an investment, and hence few have any real interest in selling, at least for the present. Nonetheless, there are some farmers who have acquired land as a speculative venture, held it for several years, without necessarily developing it, until the price increased sufficiently, and then sold it before buying more land further out in the peri-urban zone from the city and repeating the process at a later date.

A third trend can be seen in Table 2 with reference to the production priorities of farmers. Food crop farmers are both more likely to sell land and to leave farming than are cash crop producers. Discussions with farmers in the survey suggested that this is because many of them now see that the survival demands by households for food crop production in the 1980s and early 1990s are significantly less pressing in the later 1990s; hence food crop farmers are rather more sanguine about selling land and leaving farming. On the other hand, cash crop farmers are more reluctant to sell land as they see a possible market niche for peri-urban crops.

It is clear, therefore, that for most farmers, the peri-urban zone in the later 1990s has become more than simply a zone of survival for the urban poor. For many, there are now decisions to be taken about whether to sell land or not, and, indeed, whether to leave farming or not, something which few would have been prepared to contemplate a decade ago. Land has become a saleable commodity. Even though the legal position of the state is that there is no official land market in Tanzania (Shivji, 1995; Kironde, 1995), it is clear from discussions with periurban farmers and others that, since the early 1990s, the land market has become increasingly strong and volatile, and demands, if anything, are increasing,

\section{Processes in the development of a land market in peri-urban Dar-es-Salaam}

For most of the 1980s, during the first few years of structural adjustment, much of the spatial expansion of Dar-es-Salaam's peri-urban zone was related to a survival strategy on the part of many city residents, and hence closely concurred with the thinking outlined in the earlier part of this paper (Briggs, 1991; Sawio, 1993; Mlozi, 1997). Many moved to the edge of the urban area from the city itself, primarily as a need for households to produce food themselves to survive the severe economic crisis of the early and mid-1980s. These areas offered people opportunities to engage in farming, and hence to secure a household food supply, whilst also allowing them to engage in non-farm jobs in the city wherever possible. Strategies included retaining a house in the city, whilst, at the same time, having one or two household members working on a peri-urban farm; other households moved out of the city completely and built houses at the edge of the urban area. At this time, settlement tended to locate along the major arterial roads 
to enjoy easier transport services to and from the city, rather than being located on less accessible off-road sites.

In the early 1990s, however, the processes started to change in response to the easing economic crisis in Tanzania, and in Dar-es-Salaam in particular. People no longer had to respond to earlier economic crisis conditions by using the peri-urban zone as a zone of survival, rather it started to become a zone for investment. Increasingly, the development of permanent housing took place, as well as the expansion of commercial agriculture, typified by products such as fresh milk, vegetables (especially mchicha, a leafy vegetable not unlike spinach), oranges and other fruit (Mlozi et al., 1992). It is clear, therefore, that by the mid-1990s, the peri-urban zone of Dar-es-Salaam had moved from being a zone of survival to one of investment, and, indeed, of speculation in some parts. As the Tanzanian economy started to stabilise, households increasingly saw the peri-urban zone as one providing investment opportunities in terms of housing developments, as well as generating income-earning opportunities from agricultural production for the urban food market.

These changes have been encouraged by a number of enabling factors. Firstly, Tanzania's engagement since the mid-1980s with structural adjustment programmes (SAPs) has impacted on land use in the peri-urban zone. Structural adjustment in Tanzania specifically, and in Africa generally, aims to replace statebased economic interventions by market mechanisms and to balance national incomes and expenditures, reflecting ideological commitments to market economics and capitalism (Gibbon, 1993, 1995; Simon, 1992; Simon et al., 1995; Rapley, 1996). Among the measures taken have been a significant reduction in the government's involvement in the economy, which in reality has meant the privatisation of nationalised industries and the introduction and encouragement of competition within various key economic sectors; trade liberalisation; the abolition of centrally-fixed currency exchange rates; and the deregulation of currency markets. As economic confidence has grown, potential domestic investors have looked for investment opportunities as neoliberal free market principles started to dominate development discourses and practice. Land in the peri-urban zone, therefore, has increasingly become a desired commodity, and especially so for investment in house construction, on the grounds that housing is seen as a safe investment for several reasons. Firstly, it provides security in the case of retrenchment and, indeed, for retirement. Secondly, in the event of government renationalisation, housing is likely to be one of the last sectors to be nationalised. Thirdly, housing can provide an additional source of income by renting out rooms op, indeed, the whole house, sometimes to government ministries who then rent it back to employees, typically at $12.5 \%$ of salary. Finally, the house provides an initial secure base for other family members or kin migrating to Dar-es-Salaam from up-country. Hence, land in the peri-urban zone has developed a market value and has become increasingly commoditised. This has contributed to the development of a vibrant land market in Dar-es-Salaam.

At the same time as structural adjustment measures have modified the macroeconomic conditions under which a land market could develop, other more local pressures have also contributed to the development of a peri-urban land market. In particular, deficiencies in public land management have resulted in 
the evolution of informal land markets in the peri-urban zone of Dar-es-Salaam. According to Kombe (1994), a combination during the 1980s and early 1990s of poor national economic performance at the macroscale, and unresponsive land management concepts at the microscale, have generated a demand for land, which, in turn, has led to the development of an informal land market. The continuing denials by state representatives of a de facto private, informal urban and peri-urban land market can no longer be sustained. This is very different from the de jure position, whereby all land title has been vested in the state since 1923 with the colonial Land Ordinance which established that all land in Tanganyika, as it was then known, was declared to be public land. This position was strengthened by the Land Acquisition Act of 1967, which, in the spirit of the Arusha Declaration, confirmed that all land was state land through nationalisation, and, as such, the formal sale, purchase and rental of land by individuals was illegal. Hence, land in Tanzania officially has no monetary value and, as such, it is nonmarketable. As all land titles are legally vested in the state, land can theoretically only be allocated by the state to individuals on a leasehold basis, typically 33 or 99 years. In Dar-es-Salaam, urban land allocation is approved by the Ministry of Lands, Housing and Urban Development, although Dar-es-Salaam city council also lay claim to this responsibility.

However, the allocation system has been unable to deal satisfactorily with demand for both urban and peri-urban land in Dar-es-Salaam. Between 1978 and 1992, there were 261,788 applications for land registration in Dar-es-Salaam, but only 17,751 (fewer than $6 \%$ ) were processed over that time period, an average of fewer than 1500 per year (Kombe, 1994). Assuming that most of the remainder of the unprocessed applicants have settled on the land for which they have formally applied for registration, this suggests that a large proportion of the population of Dar-es-Salaam has had to use the informal land market to get access to living space. Indeed, it has been suggested that $70 \%$ of Dar-es-Salaam's population live in unplanned areas, that is, land which is obtained through informal means (Kironde, 1995). It can be easily argued, therefore, that informal land sales have replaced the formal state allocation system as the main vehicle for the delivery of land in the urban and peri-urban areas of Dar-es-Salaam. An unmet demand, a demand which the state is unable to satisfy, has resulted in the development of a well-organised informal land delivery system. As the state still fails to recognise the existence of an informal land market, the Tanzanian government is losing revenue; indeed, if the existence of a private land market were to be legally recognised, the state could then at least set in place a tax system on land sales as a revenue-generating activity.

The problem, however, is further compounded by the suggestion that the state monopoly in the de jure land allocation system has resulted in the development of corrupt activities in the formal land allocation process. In a devastating critique of the urban land management system in Dar-es-Salaam, Kombe (1994, 29) states that ' $[\mathrm{m}]$ ost interviewees conceded that today it would be inconceivable for one to expect to be formally allocated a plot just because they [sic] had applied for one'. In his survey, Kombe shows that $17 \%$ of interviewees had bought land privately from only two sellers who were also senior employees of Dar-es-Salaam City Council; he further noted that $69 \%$ of those in the survey also 
happened to be public servants. This comments are not new. Many depositions to the Presidential Commission on Land Matters made reference to inefficient, illegitimate, unjust and corrupt behaviour by state officials in land allocations and in resolving land disputes (United Republic of Tanzania, 1992). The reality of the informal land market in Dar-es-Salaam, therefore, undermines such corrupt or rent-seeking activities, and provides opportunities for investors to compete for land on a more even playing-field.

Typically, the peri-urban land market currently operates through agents whose role is to bring together buyers and sellers. It would be misleading to describe most of these individuals as professional estate agents, firstly because, strictly speaking, they are acting illegally on the basis that the state still denies the existence of a private land market; and, secondly, because most agents are not full-time, and engage in these activities as one element of a portfolio of business interests. The agent acts as a facilitator between the two parties, a price is agreed, and the agent takes a percentage fee, usually in the range of 5 to $15 \%$ of the transaction total. The deal is then registered, in front of witnesses, sometimes with a balozi ( 10 cell leader), but, increasingly, with the village or community chairman. ${ }^{2}$ At this point, land ownership is established de facto in the community, and for many this is as far as it goes. Many purchasers do go on to attempt to survey the land formally and register it with the Ministry of Lands, but it is at this stage that the system largely breaks down for the reasons described earlier.

Two important issues, however, are emerging in relation to the developing land market. Firstly, there has emerged a serious confusion over the nature of land law and ownership in Tanzania, and especially so in the urban areas. Much of this confusion can be traced back to, firstly, colonial law which worked on the assumption that registered land, usually in the urban areas, was governed by statutory law, and unregistered land, usually rural, by customary law, a division that has passed down in practice into the post-colonial era; and, secondly, to the state maintaining that all land rights are vested with it and not with private landowners (Shivji, 1995; United Republic of Tanzania, 1995). Although land ownership arrangements in Tanzania's rural areas generally operate under customary law, the situation is far less clear-cut in the urban and especially periurban areas. In the urban areas, where there has been a well-established tradition of registered land since early colonial times, land ownership operates under statutory law. The situation, however, is far less clear with regard to peri-urban land in Dar-es-Salaam, which is, or has recently been, rural. Land 'ownership' here has largely been determined by customary tenure. However, as this customary land is 'sold', legal ownership rights are raised with significant potentials for disputes over land 'ownership'. The increasing commodification of land and subsequent development of a vibrant informal land market has served only to aggravate the situation. Importantly, the Presidential Land Commission found that few people had confidence in the machinery for resolving land disputes (United Republic of Tanzania, 1992). Interestingly, the Commission report recommended, among other things, that land titles should be vested at the village or community level and that disputes should be resolved at the local level by village or community assemblies, and not by the state. This was rejected by the Tanzanian Government, and currently represents a significant impasse. A highly 
significant ruling by the Tanzanian Court of Appeal in December 1998, however, does little to clarify the situation, in that it confirmed that whilst customary law was upheld in rural areas, statutory law held good in urban environments. The case, however, related to the ownership of a plot of land in 1978 in Magomeni in Dar-es-Salaam, which, at that time, was unequivocally rural, and hence subject to customary law ownership, but now is equally unequivocally urban, and hence, in this ruling, subject to statutory law. Consequently, the original customary law owners were now found to be squatting on land that had been farmed by their families for a number of generations, and ownership rights have now legally passed to the statutory law owners.

A second issue concerns the way in which the character of the peri-urban zone has been changing in the latter half of the 1990s. As it has changed from a zone of survival to a zone of investment and opportunity, less well-off people have been bought out, or indeed have been excluded in the first place, by wealthier individuals or interest groups. In a survey of six of the main cities of Tanzania, the majority of the urban poor who were interviewed felt that their agricultural future was increasingly threatened because of problems of securing sufficient land in the peri-urban areas, as well as securing access to other productive resources (Mlozi et al., 1992). With specific reference to Dar-es-Salaam, Sawio (1994) reports that many farmers in the peri-urban and urban areas of the city have high educational attainment levels and many are high income earners; indeed, in Dar-es-Salaam there is a dominance in peri-urban and urban farming by three occupational classes, these being small business entrepreneurs (19\%); professionals (16\%); and full-time urban cultivators (11\%). Peri-urban and urban agriculture is no longer a marginal activity. It has become far more than simply the urban survival activity which it once was, and it has become pluri-structured in the sense that it now involves a complex mix of operators and not just the urban poor. As Sawio $(1994,28-29)$ puts it:

Although urban agriculture is practised by rich and poor alike, some of the former may practice it not so much for the need to survive in the city because of poverty, but rather for the lucrative commercial opportunities it offers.

There is an argument, therefore, that structural adjustment conditions have yet again militated against the urban poor, and have very much benefited the emerging urban 'middle class' in the peri-urban zone. Under the neoliberal conditions put in place by structural adjustment, this latter group has been able to take advantage of the emerging urban land market, having access to capital, expertise and 'contacts'. As part of this process, there has been a commodification of land, encouraged by opportunities for the expansion of commercial crop production for the urban food market of Dar-es-Salaam, or for investment in house-building as a capital investment, both of which, indeed, create further opportunities for capital accumulation. Consequently, the losers tend to be the urban poor; indeed, as Smith $(1998,214)$ has observed: '[i]n these complex circumstances, the interests of the poor are permitted only as long as they do not threaten more profitable activities such as commercial farming, recreational land uses and the like'. Although not yet applicable to Dar-es-Salaam, a newly emerging further threat to the rights of the urban poor in other East African cities, such as Nairobi 
and Arusha, is the expanding production of high-value export crops (for example, horticultural products and cut flowers) in the peri-urban zone, due to easy access to international airports for export to European markets. Once again, it is the conditions brought about by structural adjustment which have promoted such activities.

\section{Conclusions}

It is clear from the above discussion of recent processes in the peri-urban zone of Dar-es-Salaam that economic events and pressures have moved on from some of the earlier representations of the late 1980s and early 1990s. Representations of the African peri-urban zone as a zone of agriculture being undertaken as a subsistence response by the urban poor to urban economic pressures now undervalues the complexity, dynamism and pluriactive nature of the contemporary African peri-urban zone. Views that the peri-urban zone can be characterised as an area where the urban poor farm to survive under stress conditions produced by structural adjustment measures is less convincing as an explanation now than it was ten years ago. Farmers and, significantly, investors from middle-income groups, as well as entrepreneurs with access to investment and venture capital, have now become competitors for peri-urban land. In this respect, Sawio's (1994) observation that peri-urban farmers in Dar-es-Salaam come from all income groups is important, and hence we should not be surprised that a vibrant land market in Dar-es-Salaam has evolved to satisfy these demands. Indeed, this is reinforced by opportunities for the expansion of commercial agricultural production, opportunities which are promoted by the presence of the adjacent large urban market of Dar-es-Salaam. Hence, the view that 'urban agriculture is far from being merely a poor person's subsistence, an informal activity or an illegal business' (Egziabher et al., 1994, 24) becomes all the more convincing. Circumstances have moved on from a decade or so ago, when the peri-urban zone could be confidently characterised as a zone of urban survival.

An important consequence of these developments, however, is the way in which low-income groups have been increasingly squeezed and excluded from peri-urban land. During the 1980s economic crisis, peri-urban land had a survival quality to it, in the sense that plots were farmed by households for food, and hence the availability of family labour constrained the amount of land that could be cultivated. Few households were able to farm, or had the capital to buy, large plots of land. Hence, land pressures were not particularly marked, and there was little differentiation between wealthier and poorer families in terms of access to periurban 'survival' land. However, as the economic crisis eased, and as land has become increasingly commoditised, the urban poor have in turn become increasingly excluded. Whilst some of the wealthier urban groups have benefited from the opportunities created by structural adjustment, there is little doubt that, in the peri-urban zone at least, the increasing exclusion of the poor has increased their vulnerability to continuing urban economic pressures.

A final issue concerns the increasingly sensitive issue of land ownership, and a critical problem for the emerging land market of Dar-es-Salaam is the establishment of clear ownership rights. This is not a new problem, neither in Tanzania, nor elsewhere in Africa. Rakodi (1985), for example, draws attention 
to the fact that, even at that time, many people farming in the peri-urban zones of African cities did not know who owned the land they were cultivating. However, it has now become more pressing because of the process of land commodification. In Tanzania, land law appears to de definitive in the sense of recognising the distinction between rural areas (customary law) and urban areas (statutory law). In practice, however, this breaks down when an urban area, such as Dar-esSalaam, is expanding so rapidly and spatially into its rural surrounds, a situation aggravated by confusion as to whether peri-urban land is rural or urban land. Land ownership disputes are increasing, and these are likely to intensify as land values increase. This is arguably the next most pressing problem to be addressed in the African peri-urban zone.

\section{Notes}

1. The exchange rate in August 1999 was US $\$ 1$ equals TShs (Tanzanian Shillings) 780.

2. A balozi, or 10-cell leader, is a person who has responsibility over a group of approximately 10 households in a community. This system was originally set up in the 1970s by the then-ruling party, Chama cha Mapinduzi (CCM), as a way of democratising and giving political responsibility to individual households in the community. With the advent of multi-party politics in the 1990s, and, indeed, a considerable amount of scepticism and cynicism within communities about the reality of the politicised balozi system, it has now fallen into disuse in many areas.

\section{References}

Briggs, J. (1990). Food crop marketing in the peri-urban zone of Dar-es-Salaam. In Findlay, A., Paddison, R. \& Dawson, J.A. (eds), Retailing environments in developing countries (Routledge: London), 181-194.

Briggs, J. (1991). The peri-urban zone of Dar-es-Salaam, Tanzania: recent trends and changes in agricultural land use. Transactions, Institute of British Geographers 16, 319-333.

Bryant, C.R. \& Johnson, T.R.R. (1992). Agriculture in the city's countryside (Belhaven Press: London).

Drakakis-Smith, D.W. (1991). Urban food distribution in Asia and Africa. Geographical Journal 157, 51-61.

Drakakis-Smith, D.W. (1994). Food systems and the poor in Harare under conditions of structural adjustment. Geografiska Annaler 76B, 3-20.

Egziabher, A., Lee-Smith, D., Maxwell, D., Memon, P., Mougeot, L. \& Sawio, C. (1994). Cities feeding people: an examination of urban agriculture in East Africa (International Development Research Centre: Ottawa).

Freeman, D.B. (1991). A city of farmers: informal urban agriculture in the open spaces of Nairobi, Kenya (McGill-Queen's University Press, Montreal).

Gefu, J.O. (1992). Part-time farming as an urban survival strategy: a Nigerian case study. In Baker, J. \& Pedersen, P.O. (eds), The rural-urban interface in Africa: expansion and adaptation (The Scandinavian Institute of African Studies, Uppsala), 295-302.

Gibbon, P. (1993). Social change and economic reform in Africa (Nordiska Afrikainstitutet, Uppsala).

Gibbon, P. (1995). Liberalised development in Tanzania (Nordiska Afrikainstitutet, Uppsala). 
Kironde, J.M.L. (1995). Access to land by the urban poor of Tanzania: some findings from Dar-es-Salaam. Environment and Urbanisation 7, 77-95.

Kombe, J.W.M. (1994). The demise of public urban land management and the emergence of the informal land markets in Tanzania: a case of Dar-esSalaam city. Habitat International 18, 23-43.

Lado, C. (1990). Informal urban agriculture in Nairobi, Kenya: problem or resource in development and land use planning? Land Use Policy 7, 257266.

Maxwell, D. (1995). Alternative food security strategy: a household analysis of urban agriculture in Kampala. World Development 23, 1669-1681.

Maxwell, D. (1996). Highest and best use? Access to urban land for semisubsistence food production. Land Use Policy 13, 181-195.

Mbiba, B. (1994). Institutional responses to uncontrolled urban cultivation in Harare: prohibitive or accommodative? Environment and Urbanisation 6, 188-202.

Memon, P.A. \& Lee-Smith, D. (1993). Urban agriculture in Kenya. Canadian Journal of African Studies 27, 25-42.

Mlozi, M.R.S. (1997). Urban agriculture: ethnicity, cattle raising and some environmental implications in the city of Dar-es-Salaam. African Studies Review 40 (3), 1-28.

Mlozi, M.R.S., Lupanga, I.J. \& Mvena, Z.S.K. (1992). Urban agriculture as a survival strategy in Tanzania. In Baker, J. \& Pedersen, P.O. (eds), The ruralurban interface in Africa: expansion and adaptation (The Scandinavian Institute of African Studies, Uppsala), 284-294.

Mortimore, M. (1975). Peri-urban pressures. In Moss, R.P. \& Rathbone, J. (eds), The population factor in African studies (London University Press, London)

Mosha, A.C. (1991). Urban farming practices in Tanzania. Review of Rural and Urban Planning in Southern and Eastern Africa 1, 83-92.

Rakodi, C. (1985). Self-reliance or survival? Food production in African cities with particular reference to Lusaka. African Urban Studies 21, 53-63.

Rakodi, C. (1988). Urban agriculture: research questions and Zambian evidence. Journal of Modern African Studies 26, 495-515.

Rakodi, C. (1995). Poverty lines or household strategies? A review of conceptual issues in the study of urban poverty. Habitat International 19, 407-426.

Rapley, J. (1996). Understanding development: theory and practice in the Third World (UCL Press: London).

Rogerson, C. (1993). Urban agriculture in South Africa. Development Southern Africa 10, 33-44.

Sanyal, B. (1986). Urban cultivation in East Africa (United Nations University (Food and Energy Nexus Programme): Tokyo).

Sanyal, B. (1987). Urban cultivation amidst modernization: how should we interpret it? Journal of Planning Education and Research 6, 197-207.

Sawio, C. (1993). Feeding the urban masses? Towards an understanding of the dynamics or urban agriculture and land use change in Dar-es-Salaam, Tanzania. Unpublished PhD thesis, Clark University, Worcester, Massachusetts. 
Sawio, C. (1994). Who are the farmers of Dar-es-Salaam? In Egziabher, A. et al. (eds), Cities feeding people: an examination of urban agriculture in East Africa (International Development Research Centre: Ottawa), 25-46.

Shivji, I. (1995). Contradictory perspectives on rights and justice in the context of land tenure reform in Tanzania. Economic Research Bureau, University of Dar-es-Salaam, Discussion Paper.

Simon, D. (1992). Cities, capital and development: African cities in the world economy (Belhaven Press: London).

Simon, D., van Spengen, W., Dixon, C. \& Narman, A. (eds) (1995). Structurally adjusted Africa: poverty, debt and basic needs (Pluto Press: London).

Smith, D.W. (1998). Urban food systems and the poor in developing countries. Transactions, Institute of British Geographers 23, 207-219.

Swindell, K. (1988). Agrarian change and peri-urban fringes in tropical Africa. In Rimmer, D. (ed.), Rural transformation in tropical Africa (Belhaven Press: London), 98-115.

United Republic of Tanzania (1992). Report of the Presidential Commission of Enquiry into Land Matters. (In association with the Scandinavian Institute of African Studies: Uppsala.)

United Republic of Tanzania (1995). National Land Policy (Ministry of Lands, Housing and Urban Development: Dar-es-Salaam). 